\title{
The Effect of Learning Style, Emotional Intelligence, and Adversity Quotient on the Second-grade Students' Mathematics Learning Achievement of Islamic Senior High School
}

\author{
Rezki Awalia Ainun, Rosidah*, \& Hamda \\ Department of Mathematics, Universitas Negeri Makassar, Makassar, Sulawesi Selatan, Indonesia
}

\begin{abstract}
This research aims to determine the effect of learning style, emotional intelligence, and adversity quotient on the second-grade students' mathematics learning achievement of Islamic Senior High School. The type of this research is ex post facto, where the total sample used is 100 students selected using random sampling technique. The data was obtained through a learning style questionnaire, emotional intelligence, adversity quotient, and mathematics learning achievement tests. The data were analyzed using descriptive statistics and inferential statistics using multiple linear regression analysis. The result showed that: (1) There is no difference in the type of learning style in affecting students' mathematics learning achievement. (2) Students' emotional intelligence has a positive but not significant effect on their mathematics learning achievement. (3) Students' Adversity quotient has a positive but not significant effect on their mathematics learning achievement. (4) Learning style, emotional intelligence, and adversity quotient have no significant effect on students' mathematics learning achievement.
\end{abstract}

Keywords: learning style, emotional intelligence, adversity quotient, learning achievement.

\section{Introduction}

Tinggi atau rendahnya prestasi belajar matematika seseorang dapat dipengaruhi oleh beberapa faktor, yakni faktor internal dan faktor eksternal. Faktor internal merupakan faktor yang berasal dari dalam diri seseorang diantaranya faktor fisiologis/jasmani (kesehatan, dan cacat tubuh) dan faktor psiokologis (intelegensi/kecerdasan, minat, bakat, dan motivasi). Sedangkan faktor eksternal merupakan faktor yang berasal dari luar diri seseorang, diantaranya faktor keluarga, faktor lingkungan sekolah dan faktor masyarakat (Slameto, 2015).

Hasil evaluasi PISA (Programme for International Student Asessment) tahun 2018, Indonesia mendapat skor 379 untuk bidang matematika. Sedangkan hasil evaluasi PISA tahun 2015, menunjukkan Indonesia mendapatkan skor 386 pada bidang matematika. Dari hasil tersebut menunjukkan skor Indonesia pada evaluasi PISA sebelumnya mengalami penurunan, juga prestasi rata-rata siswa dalam bidang matematika terbilang rendah dibandingkan dengan negaranegara lainnya. Berkaitan dengan itu, dalam rangka mewujudkan prestasi belajar matematika siswa yang lebih baik maka diperlukan adanya inovasi-inovasi proses belajar yang dapat mengembangkan potensi internal dari setiap pribadi siswa. Diantara potensi itu adalah gaya belajar, kecerdasan emosional, dan advertisy quotient.

Setiap siswa memiliki cara untuk menyerap dan mempelajari informasi-informasi baru yang didapat dari lingkungan sekitarnya, begitupun dengan materi pelajaran yang disampaikan di kelas. Jika siswa diajar dengan metode yang standar, kecil kemungkinan siswa dapat paham sepenuhnya dengan materi yang diajarkan. Menurut Deporter dan Hernacki (2009) gaya belajar adalah kombinasi dari bagaimana seseorang manyerap dan kemudian mengatur serta mengelolah informasi. Gaya belajar secara umum adalah cara yang dipilih seseorang untuk menyerap dan mengelolah informasi dengan mudah. Kemampuan seseorang dalam menyerap dan mengelolah informasi juga berbeda. Oleh karena itu, mereka harus menempuh suatu cara tertentu untuk dapat memahami sebuah informasi atau pelajaran yang sama.

* Corresponding author.

E-mail address: rosidah.unesa@gmail.com (Rosidah) 
Lebih lanjut Uno (2006) menyatakan bahwa apapun cara yang dipilih, perbedaan gaya belajar itu menunjukkan cara tercepat dan terbaik bagi setiap individu untuk bisa menyerap sebuah informasi dari luar dirinya. Dengan mengetahui gaya belajar siswa, guru dapat menggunakan berbagai metode yang dapat membantu menyampaikan informasi atau materi dengan menggunakan gaya yang berbeda-beda sesuai dengan gaya belajar siswa. Gaya belajar seseorang dapat digolongkan menjadi tiga jenis, diantaranya gaya belajar visual, auditorial dan kinestetik. Gaya belajar visual adalah cara siswa menyerap informasi dengan lebih baik melalui apa yang dilihat. Gaya belajar auditorial adalah cara siswa menyerap informasi dengan lebih baik melalui apa yang didengar. Sedangkan gaya belajar kinestetik adalah cara siswa menyerap informasi dengan lebih baik melalui gerakan dan sentuhan.

Beberapa penelitian terkait yang telah dilakukan sebelumnya mengenai gaya belajar siswa, (Bire, dkk, 2012; Prihatin, 2017; Rahman dan Ahmar, 2017;Widyawati, 2016). Penelitian yang dilakukan oleh Bire, dkk (2014) menunjukkan bahwa Gaya belajar visual, auditorial dan kinestetik secara bersama-sama berpengaruh secara positif dan signifikan terhadap variabel prestasi belajar siswa. Selain itu, penelitian yang dilakukan oleh Widyawati (2016) juga menunjukkan bahwa mahasiswa yang memiliki gaya belajar visual dan auditorial memiliki prestasi belajar yang lebih baik daripada mahasiswa yang memiliki gaya belajar kinestetik.

Selain gaya belajar, ada faktor lain yang dapat mempengaruhi prestasi belajar matematika siswa, salah satunya adalah kecerdasan. Kecerdasan merupakan hal yang dimiliki oleh setiap siswa, yang membedakan hanyalah tingkat kecerdasan antara siswa satu dengan yang lainnya. Sering kita mendengar bahwa kecerdasan intelektual (IQ) sangat penting dalam proses belajar. Sejak lama pemahaman bahwa IQ dianggap penting dalam meraih kesuksesan di masa depan. Namun terkadang seseorang dangan IQ tinggi dapat dikalahkan oleh orang yang memiliki kecerdasan emosional yang tinggi. Menurut Goleman (2002), IQ hanya menyumbang 20\% bagi kesuksesan seseorang, sedangkan $80 \%$ adalah sumbangan dari faktor-faktor lain, diantaranya kecerdasan emosional yaitu kemampuan memotivasi diri sendiri, mengatasi frustasi, mengontrol desakan hati, mengatur suasana hati, berempati serta kemampuan bekerjasama.

Kecerdasan emosional adalah kemampuan seseorang dalam mengendalikan emosinya, serta mampu merasakan, memahami dan mengontrol emosinya sendiri dan orang lain sehingga mampu mengelolah emosi tersebut untuk membimbing pikiran untuk mengambil keputusan terbaik dan menjadi berguna untuk hal-hal yang baik. Goleman (2002) menyatakan ada lima domain utama dalam kecerdasan emosional, yaitu kesadaran diri, pengaturan diri, motivasi, empati, dan keterampilan sosial. Kecerdasan emosional ini sangat berpengaruh karena juga menyangkut kemampuan dalam mengendalikan emosi dan beradaptasi dengan lingkungan.

Penelitian terkait yang juga membahas mengenai kecerdasan emosional, (Alzak dan Rustam, 2015; Aswin, 2018; Daud, 2012). Penelitian yang dilakukan oleh Daud (2012) menyatakan bahwa ada pengaruh yang positif dan signifikan variabel kecerdasan emosional terhadap hasil belajar siswa. Kemudian Aswin (2018) juga dalam penelitiannya menyatakan bahwa kecerdasan emosional berpengaruh positif dan signifikan terhadap prestasi belajar siswa.

Keberhasilan siswa dalam belajar juga tergantung pada bagaimana siswa tersebut mengatasi kesulitan yang ada. Adversity quotient atau lebih dikenal dengan istilah AQ dikembangkan oleh seorang konsultan bisnis yang dikenal dengan nama Paul G. Stoltz. Stoltz mendefinisikan AQ adalah kemampuan seseorang dalam mengamati kesulitan dan mengolah kesulitan tersebut dengan kecerdasan yang dimiliki sehingga menjadi sebuah tantangan untuk menyelesaikannya. Leonard dan Amanah (2014) mendefinisikan secara sederhana AQ sebagai kecerdasan individu dalam menghadapi kesulitan-kesulitan, hambatan-hambatan maupun tantangan dalam hidup. Secara umum dapat didefinisikan adversity quotient adalah kecerdasan yang dimiliki seseorang/siswa dalam menghadapi kesulitan atau masalah dan dapat mengubahnya menjadi peluang dan tantangan untuk diselesaikan.

AQ yang dimiliki oleh setiap siswa dapat membantu untuk mengatasi masalah yang terjadi saat proses belajar berlangsung. Daya juang yang tinggi yang dimiliki oleh siswa juga sangat penting untuk membantu bagaimana siswa dapat menyelesaikan masalah dan tidak menyerah terhadap kesulitan-kesulitan yang dialami ketika dalam proses belajar mengajar. Stoltz (2005) membagi AQ menjadi 3 kelompok, yakni climber, camper dan quitter. Climber adalah mereka yang terus berjuang dan bertahan menghadapi masalah atau kesulitan. Dalam pembelajaran, siswa climber adalah mereka yang memiliki target dan terus berjuang untuk mendapatkan hasil yang maksimal dengan ulet dan gigih. Camper adalah mereka yang menunjukkan sedikit semangat dan beberapa usaha dalam menghadapi masalah atau kesulitan, namun mudah menyerah dan tidak mau mengambil resiko besar. Dalam pembelajaran, siswa camper adalah mereka yang sudah berusaha namun menyerah atau berhenti karena beberapa faktor, sehingga mereka cepat merasa puas atas hasil yang diperoleh. Quitter adalah mereka yang kurang berusaha dan mudah menyerah ketika 
menghadapi masalah atau kesulitan dalam hidupnya. Dalam pembelajaran, siswa quitter adalah mereka yang menganggap pelajaran itu sulit namun tidak ada usaha untuk belajar dan mudah putus asa dalam menghadapi persoalan yang dihadapi.

Beberapa penelitian terkait yang telah dilakukan sebelumnya yang membahas mengenai AQ (Hasanah, 2010; Leonard dan Amanah, 2014; U.S, 2013; Wardiana, dkk, 2014). Hasil penelitian Leonard dan Amanah (2014) menunjukkan bahwa AQ memberikan pengaruh positif dan signifikan terhadap prestasi belajar matematika siswa. Wardiana dkk (2014) juga menyatakan bahwa ada hubungan positif signifikan antara AQ dengan prestasi belajar matematika siswa.

Penelitian ini bertujuan untuk mengetahui gaya belajar, kecerdasan emosional, dan AQ yang dimilliki oleh siswa. Selain itu, penelitian ini juga bertujuan untuk mengetahui ada atau tidaknya pengaruh dari gaya belajar, kecerdasan emosional, dan AQ secara bersama-sama ataupun pengaruh dari masing-masing variabel tersebut terhadap prestasi belajar matematika siswa.

\section{Research Methods}

Jenis penelitian yang digunakan dalam penelitian ini adalah penelitian kuantitatif dengan jenis penelitian ex post facto. Populasi dalam penelitian ini berjumlah 331 siswa, kemudian dipilih sampel penelitian sebanyak 100 orang siswa dengan menggunakan teknik random sampling. Adapun desain penelitian ini adalah sebagai berikut:

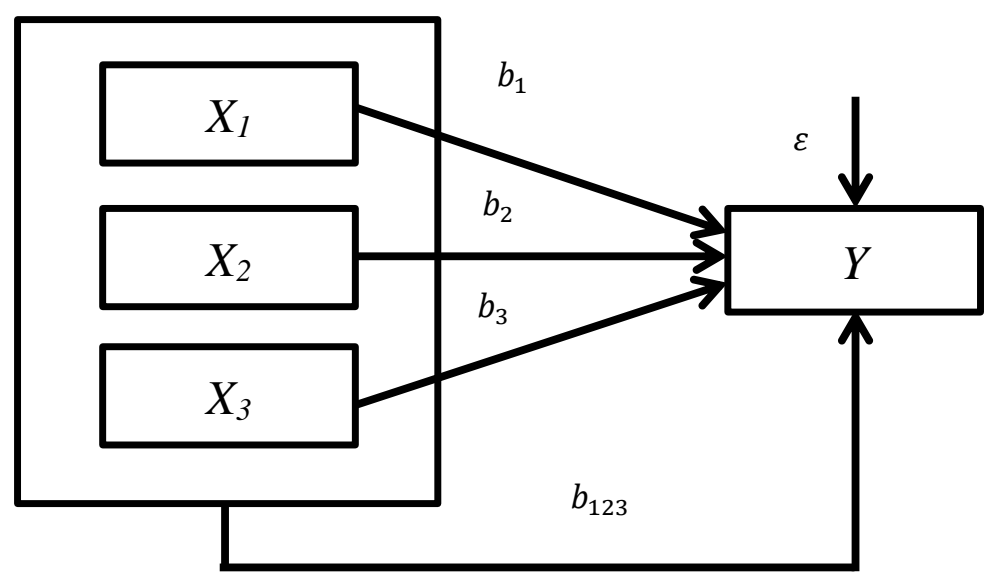

Gambar 1. Desain Penelitian

Berdasarkan diagram pada gambar 1, dapat dituliskan model persamaan strukturalnya sebagai berikut :

$$
\mathrm{Y}=a+b_{1} D_{1}+b_{2} D_{2}+b_{3} D_{3}+b_{4} D_{4}+b_{5} D_{5}+b_{6} D_{6}+b_{7} X_{2}+b_{8} X_{3}+\varepsilon
$$

Keterangan :

a = nilai konstanta

$b_{(1,2 \ldots n)} \quad=$ nilai koefisien regresi

$D_{1} \quad=\operatorname{variabel}$ dummy (1 jika gaya belajar visual, 0 jika tidak)

$D_{2} \quad$ = variabel dummy (1 jika gaya belajar auditorial, 0 jika tidak $)$

$D_{3} \quad$ = variabel dummy (1 jika gaya belajar kinestetik, 0 jika tidak)

$D_{4} \quad=$ variabel dummy (1 jika gaya belajar visual dan auditorial, 0 jika tidak )

$D_{5} \quad$ = variabel dummy (1 jika gaya belajar visual dan kinestetik, 0 jika tidak)

$D_{6} \quad=$ variabel dummy (1 jika gaya belajar auditorial dan kinestetik, 0 jika tidak)

$X_{2} \quad=$ Kecerdasan Emosional

$X_{3} \quad=$ Adversity Quotient

$Y \quad=$ Prestasi Belajar Matematika

$\varepsilon \quad=$ Error $/$ Variabel residu 
Variabel dalam penelitian ini terbagi menjadi dua, yakni variabel terikat dan variabel bebas. Variabel terikat dalam penelitian ini adalah prestasi belajar matematika siswa, dan variabel bebas dalam penelitian ini adalah gaya belajar, kecerdasan emosional dan adversity quotient dengan variabel gaya belajar sebagai variabel dummy. Teknik yang digunakan dalam pengumpulan data yaitu dengan tes dan kuisioner. Instrumen yang digunakan dalam penelitian ini yaitu tes prestasi belajar matematika, dan kuisioner gaya belajar, kecerdasan emosional dan adversity quotient.

Data yang telah terkumpul kemudian diolah dengan teknik analisis statistik, yakni analisis statistik deskriptif dan analisis statistik inferensial dengan menggunakan analisis regresi linear berganda.

\section{Results and Discussion}

All.

\subsection{Hasil Analisis Statistik Deskriptif}

\subsubsection{Prestasi belajar matematika}

Tabel 1. Statistik Nilai Prestasi Belajar Matematika Siswa

\begin{tabular}{lc}
\hline \multicolumn{1}{c}{ Deskripsi } & Nilai statistik \\
\hline Total Sampel (N) & 100 \\
Skor ideal & 100 \\
Nilai Tertinggi (Max) & 52 \\
Nilai Terendah (Min) & 4 \\
Modus & 16 \\
Rata-rata (Mean) & 21,92 \\
Median & 24,00 \\
Standar Deviasi & 9,44 \\
Variansi & 89,04 \\
\hline
\end{tabular}

Berdasarkan tabel 1, diperoleh skor rata-rata tes prestasi belajar matematika siswa sebesar 21,92, yang artinya ratarata prestasi belajar siswa berada pada kategori sangat rendah. Standar deviasi 9,44, menunjukkan bahwa penyebaran skor prestasi belajar matematika siswa tidak terlalu besar artinya data hanya berada di sekitar nilai rata-rata.

Tabel 2. Distribusi Frekuensi dan Persentase Nilai Prestasi Belajar Matematika

\begin{tabular}{cccc}
\hline Interval & Kategori & Frekuensi & Persentase (\%) \\
\hline $85 \leq$ skor $\leq 100$ & Sangat Tinggi & 0 & $0 \%$ \\
$75 \leq$ skor $<85$ & Tinggi & 0 & $0 \%$ \\
$55 \leq$ skor $<75$ & Sedang & 0 & $0 \%$ \\
$40 \leq$ skor $<55$ & Rendah & 4 & $4 \%$ \\
Skor $<40$ & Sangat Rendah & 96 & $96 \%$ \\
\hline \multicolumn{2}{c}{ Jumlah } & 100 & 100 \\
\hline
\end{tabular}

Dari hasil pada tabel 2, dapat dilihat bahwa prestasi belajar matematika yang siswa sangat rendah. Faktor yang mempengaruhi rendahnya prestasi belajar matematika siswa berdasarkan pengamatan peneliti adalah kurangnya minat belajar dan motivasi belajar siswa terhadap pelajaran matematika, terlebih lagi karena pembelajaran secara daring, siswa tidak mendapatkan dorongan psikologis dari guru secara langsung untuk meningkatkan motivasi dan minat belajar matematika siswa. Pembelajaran secara daring juga mempengaruhi kemampuan pemahaman konsep terhadap materi yang dipelajari oleh siswa. Terlebih bagi beberapa orang, beberapa materi matematika sulit dipahami tanpa adanya penjelasan materi dan contoh penerapan yang jelas. Selain itu, keterbatasan fasilitas belajar, jaringan internet 
yang kekuatan atau kecepatannya tidak merata, dan kuota internet yang tidak selalu ada dimiliki oleh siswa adalah beberapa alasan yang menjadi faktor penghambat pembelajaran secara daring sehingga juga menjadi hal yang mempengaruhi prestasi belajar matematika siswa.

\subsubsection{Gaya Belajar}

Tabel 3. Distribusi Gaya Belajar Siswa

\begin{tabular}{|c|c|c|}
\hline Jenis Gaya Belajar & Frekuensi & Persentase (\%) \\
\hline Visual & 21 & $21 \%$ \\
\hline Auditorial & 34 & $34 \%$ \\
\hline Kinestetik & 9 & $9 \%$ \\
\hline Visual dan Auditorial & 8 & $8 \%$ \\
\hline Visual dan Kinestetik & 8 & $8 \%$ \\
\hline Auditorial dan Kinestetik & 12 & $12 \%$ \\
\hline Visual, Auditorial, dan Kinestetik & 8 & $8 \%$ \\
\hline Jumlah & 100 & $100 \%$ \\
\hline
\end{tabular}

Data variabel gaya belajar pada penelitian ini diperoleh dari skor instrumen angket yang terdiri dari 30 pernyataan yang terbagi menjadi 3 bagian, diantaranya 10 pernyataan yang mewakili gaya belajar visual, 10 pernyataan yang mewakili gaya belajar auditorial dan 10 pernyataan yang mewakili gaya belajar kinestetik. Berdasarkan tabel 3, dapat diketahui jumlah siswa pada tiap-tiap jenis gaya belajar dan beberapa siswa yang memiliki kecenderungan kepada dua atau lebih jenis gaya belajar. Dapat dilihat bahwa paling banyak siswa memiliki gaya belajar auditorial, yakni sebanyak 34 siswa (34\%). Hasil penelitian ini menunjukkan bahwa siswa cenderung mudah menangkap, mengolah dan memahami matematika dengan menggunakan gaya belajar auditorial.

\subsubsection{Kecerdasan emosional}

Tabel 4. Statistik Hasil Skor Kecerdasan Emosional Siswa

\begin{tabular}{lc}
\hline \multicolumn{1}{c}{ Deskripsi } & Nilai Statistik \\
\hline Total Sampel (N) & 100 \\
Skor ideal & 200 \\
Nilai Tertinggi (Max) & 171 \\
Nilai Terendah (Min) & 86 \\
Modus & 132 \\
Rata-rata (Mean) & 134,70 \\
Median & 135,00 \\
Standar Deviasi & 14,56 \\
Variansi & 211,89 \\
\hline
\end{tabular}

Berdasarkan tabel 4, diperoleh bahwa rata-rata skor kecerdasan emosional siswa berada pada kategori sedang. Dengan standar deviasi sebesar 14,56 yang menunjukkan bahwa penyebaran skor kecerdasan emosional siswa tidak terlalu besar.

Tabel 5. Distribusi Frekuensi dan Persentase Kecerdasan Emosional Siswa

\begin{tabular}{cccc}
\hline Interval & Kategori & Frekuensi & Persentase (\%) \\
\hline $163-200$ & Sangat Tinggi & 2 & $2 \%$ \\
$138-162$ & Tinggi & 43 & $43 \%$ \\
$131-137$ & Sedang & 49 & $49 \%$ \\
\hline
\end{tabular}




\begin{tabular}{cccc}
\hline Interval & Kategori & Frekuensi & Persentase (\%) \\
\hline $88-112$ & Rendah & 5 & $5 \%$ \\
$0-87$ & Sangat Rendah & 1 & $1 \%$ \\
\hline & Jumlah & 100 & $100 \%$ \\
\hline
\end{tabular}

Berdasarkan tabel 5, dapat dilihat bahwa kebanyakan siswa memiliki kecerdasan emosional yang sedang. Siswa yang memiliki kecerdasan emosional yang tinggi dan sangat tinggi berarti bahwa mereka telah mampu mengenali kemampuan mereka sendiri yang dapat diukur melalui kemampuannya dalam mengenali diri dan emosi, mengatur dan mengendalikan diri dan emosi, memotivasi diri, mengenali emosi orang lain, dan keterampilannya dalam kehidupan dan hubungan sosial. Sedangkan siswa yang memiliki kecerdasan emosional yang sedang mengindikasikan bahwa mereka sudah memiliki kecerdasan emosional yang baik namun kemungkinan masih belum optimal. Selain itu siswa yang memiliki kecerdasan emosional yang rendah artinya mereka masih belum dapat mengatur dan mengolah emosi mereka dan mengendalikan emosinya, serta belum mampu merasakan, memahami dan mengontrol emosinya sendiri dan orang lain.

\subsubsection{Adversity quotient}

Table 6. Statistik Skor Adversity Quotient Siswa

\begin{tabular}{lc}
\hline \multicolumn{1}{c}{ Deskripsi } & Nilai Statistik \\
\hline Total Sampel (N) & 100 \\
Skor ideal & 200 \\
Nilai Tertinggi (Max) & 200 \\
Nilai Terendah (Min) & 68 \\
Modus & 129 \\
Rata-rata (Mean) & 130,49 \\
Median & 129,00 \\
Standar Deviasi & 18,78 \\
Variansi & 352,72 \\
\hline
\end{tabular}

Tabel 7. Distribusi Frekuensi dan Persentase Adversity Quotient Siswa

\begin{tabular}{cccc}
\hline Interval & Kategori & Frekuensi & Persentase (\%) \\
\hline $166-200$ & Climber & 6 & $6 \%$ \\
$95-134$ & Camper & 65 & $65 \%$ \\
$0-59$ & Quitter & 0 & $0 \%$ \\
\hline & Jumlah & 71 & $100 \%$ \\
\hline
\end{tabular}

Dari tabel 7, dapat dilihat banyaknya siswa pada tiap-tiap kategori, yakni pada kategori climber, camper dan quitter. Adapun sisanya, yakni sebanyak 26 siswa (26\%) barada pada peralihan kategori climber-camper, sedangkan sebanyak 3 siswa (3\%) berada pada peralihan kategori camper-quitter.

Siswa yang tergolong dalam kategori climbers artinya siswa tersebut sudah memiliki kemampuan untuk menghadapi kesulitan yang berat dan terus bergerak maju dan ke atas (Stoltz, 2005). Yanti dan Syazali (2016) juga menjelaskan bahwa siswa dengan tipe climbers dalam menyelesaikan masalah matematika, mereka memiliki keyakinan yang tinggi bahwa setiap masalah pasti bisa terselesaikan, mereka tidak menyerah ataupun berputus asa sesulit apapun masalah yang dihadapi sampai mereka mendapatkan jawaban yang benar. Sedangkan siswa yang berada pada peralihan climber-camper (skor 135-165) artinya siswa tersebut sudah cukup bertahan menembus tantangan-tantangan dan memanfaatkan sebagian besar potensi yang berkembang tiap harinya (Stoltz, 2005).

Siswa yang berada dalam kategori campers berarti mereka sudah lumayan baik menempuh lika-liku hidup yang berjalan relatif lancar, namun mungkin mengalami penderitaan akibat kemunduran yang besar ataupun menjadi kecil hati dengan menumpuknya frustasi dan tantangan hidup (Stoltz, 2005). Yanti dan Syazali (2016) juga menjelaskan 
siswa kategori campers dalam menyelesaikan masalah matematika, jika mengalami kesulitan maka siswa tersebut akan tetap berusaha untuk bisa menyelesaikan masalahnya. Meski akhirnya menyerah karena memilih untuk tidak mengambil resiko dan cepat puas atas hasil yang mereka dapatkan. Sedangkan siswa yang berada dalam peralihan kategori camper-quitter (skor 60-94) akan cenderung kurang memanfaatkan potensi yang dimilikinya (Stoltz, 2005). Mereka yang berada dalam kategori quitters perlu berjuang lebih keras dan tidak gampang menyerah atas kesulitan yang dihadapi.

\subsection{Hasil Analisis Statistik Inferensial}

\subsubsection{Uji prasyarat analisis}

a) Uji Normalitas

Tabel 8. Hasil Uji Normalitas Data Penelitian

\begin{tabular}{cc}
\hline Uji Kolmogorof-Smitnov & Sig. \\
\hline Asymp. Sig. (2-tailed) & 0,181
\end{tabular}

Hasil dari tabel 8 tersebut menunjukkan bahwa nilai signifikansi pada kolom Asymp. Sig. (2-tailed) yang dihasilkan adalah 0,181 , dimana $0,181>\alpha=0,05$, maka dapat disimpulkan bahwa data tersebut berdistribusi normal.

b) Uji Multikolinearitas

Tabel 9. Hasil Uji Multikolinearitas Data Penelitian

\begin{tabular}{lcc}
\hline \multirow{2}{*}{ Model } & \multicolumn{2}{c}{ Collinearity Statistics } \\
\cline { 2 - 3 } & Tolerance & VIF \\
\hline Visual & 0,340 & 2,943 \\
Auditorial & 0,284 & 3,524 \\
Kinestetik & 0,487 & 2,052 \\
Visual-Auditorial & 0,535 & 1,869 \\
Visual-Kinestetik & 0,518 & 1,931 \\
Auditorial-Kinestetik & 0,445 & 2,246 \\
Kecerdasan Emosional & 0,855 & 1,169 \\
Adversity Quotient & 0,843 & 1,187 \\
\hline
\end{tabular}

Hasil yang ditunjukkan oleh tabel 9 tersebut atas semua variabel bebas menunjukkan nilai tolerance $>0,10$ dan nilai VIF $<10,00$, sehingga dapat disimpulkan bahwa tidak terjadi gejala multikolinearitas pada model regresi penelitian ini.

c) Uji Heteroskedastisitas

Tabel 10. Hasil Uji Heteroskedastisitas

\begin{tabular}{lc}
\multicolumn{1}{c}{ Variabel } & Sig. \\
\hline Visual & 0,530 \\
Auditorial & 0,207 \\
Kinestetik & 0,778 \\
Visual-Auditorial & 0,994 \\
Visual-Kinestetik & 0,775 \\
Auditorial-Kinestetik & 0,500 \\
Kecerdasan Emosional & 0,566 \\
Adversity Quotient & 0,474 \\
\hline
\end{tabular}


Dasar pengambilan keputusan pada uji glejser menyatakan bahwa jika nilai signifikansi $>\alpha=0,05$ untuk semua variabel bebas (independen) maka tidak terjadi gejala heteroskedastisitas. Dari data pada tabel 10 tersebut dapat dilihat bahwa nilai signifikansi setiap variabel lebih besar dari $\alpha=0,05$. Berdasarkan hal tersebut dapat disimpulkan bahwa tidak terjadi gejala heteroskedastisitas pada model regresi penelitian ini.

\subsubsection{Pengujian hipotesis}

Tabel 11. Hasil Uji Regresi Linear

\begin{tabular}{clcccc}
\hline $\begin{array}{c}\text { Uji Regresi } \\
\text { Linear }\end{array}$ & \multicolumn{1}{c}{ Variabel Bebas } & Koefisien Beta & $\begin{array}{c}\text { Sig. } \\
\text { koefisien }\end{array}$ & $\mathrm{R}^{2}$ & $\begin{array}{c}\text { Sig. } \\
\text { Anova }\end{array}$ \\
\hline \multirow{2}{*}{1} & Visual & $-0,881$ & 0,825 & 0,035 & 0,755 \\
& Auditorial & $-3,912$ & 0,301 & & \\
& Kinestetik & $-1,833$ & 0,694 & & \\
& Visual-Auditorial & $-0,500$ & 0,917 & & \\
& Visual-Kinestetik & $-6,000$ & 0,213 & & \\
& Auditorial-Kinestetik & $-3,167$ & 0,470 & & \\
\hline \multirow{2}{*}{3} & Kecerdasan Emosional & 0,050 & 0,330 & 0,010 & 0,330 \\
\hline \multirow{2}{*}{4} & Adversity Quotient & 0,078 & 0,123 & 0,024 & 0,123 \\
& Visual & $-0,816$ & 0,839 & 0,065 & 0,611 \\
& Auditorial & $-4,315$ & 0,256 & & \\
& Kinestetik & $-3,172$ & 0,507 & & \\
& Visual-Auditorial & $-0,498$ & 0,918 & & \\
& Visual-Kinestetik & $-5,207$ & 0,288 & & \\
& Auditorial-Kinestetik & $-2,165$ & 0,623 & & \\
& Kecerdasan Emosional & 0,027 & 0,631 & & \\
& Adversity Quotient & 0,086 & 0,126 & & \\
\hline
\end{tabular}

\section{a) Pengujian Hipotesis 1}

Terdapat perbedaan tipe gaya belajar dalam mempengaruhi prestasi belajar matematika siswa. Dalam hipotesis statistik adalah sebagai berikut:

$$
H_{0}: \beta_{1}=0 \quad \text { lawan } H_{1}: \beta_{1} \neq 0
$$

Berdasarkan hasil analisis pada tabel 11, uji regresi linear 1 diperoleh bahwa signifikansi anova sebesar 0,755 yang lebih besar dari $\alpha=0,05$ dan juga signifikansi koefisien tiap variabel lebih bear dari $\alpha=0,05$. Maka dengan demikian dapat disimpulkan bahwa $H_{0}$ diterima, yang berarti bahwa tidak ada perbedaan tipe gaya belajar dalam mempengaruhi prestasi belajar matematika siswa. Diketahui pula bahwa nilai $\mathrm{R}^{2}=0,035$, yang artinya variabel bebas gaya belajar menjelaskan atau memprediksi variabel terikat prestasi belajar matematika hanya sebesar 3,5\%, sisanya 96,5\% dijelaskan oleh variabel lain.

Hasil penelitian ini tidak sejalan dengan hasil penelitian yang ditemukan oleh Bire, dkk (2014) yang menyatakan bahwa gaya belajar visual, gaya belajar auditorial, dan gaya belajar kinestetik secara simultan/bersama-sama maupun secara terpisah/ masing-masing dapat mempengaruhi prestasi belajar siswa. Namun di sisi lain terdapat penelitian yang sejalan dengan hasil penelitian ini, salah satunya adalah Prihatin (2017) yang menyatakan bahwa tidak terdapat perbedaan tipe gaya belajar siswa dalam mempengaruhi hasil belajar siswa.

Hasil penelitian ini yang menunjukkan bahwa tidak ada perbedaan tipe gaya belajar siswa dalam meningkatkan prestasi belajar matematika siswa bisa terjadi karena beberapa alasan. Penggunaan metode penelitian yang berbeda ataupun kondisi dan situasi siswa saat mengisi kuisioner atau angket yang diberikan tidak maksimal. Hal tersebut juga bisa terjadi jika guru tidak mengetahui gaya belajar yang dimiliki siswa dan tidak mampu memvariasikan cara 
mengajarnya untuk membantu siswa dalam memaksimalkan gaya belajarnya dalam meningkatkan prestasi belajar matematika. Maka dari itu pentingnya guru untuk mengetahui gaya belajar yang dimiliki siswa juga dapat membantu siswa untuk bagaimana memanfaatkan gaya belajarnya secara maksimal dalam memahami materi matematika yang diberikan sehingga dapat membantu meningkatkan prestasi belajar matematikanya juga. Siswa sendiri juga perlu mengetahui dan memahami gaya belajar mana yang cocok untuk dirinya dalam memahami materi matematika yang diberikan, sehingga materi tersebut dapat dipahami dengan lebih baik.

\section{b) Pengujian Hipotesis 2}

Terdapat pengaruh positif dan signifikan kecerdasan emosional terhadap prestasi belajar matematika siswa. Dalam hipotesis statistik adalah sebagai berikut:

$$
H_{0}: \beta_{2} \leq 0 \text { lawan } H_{1}: \beta_{2}>0
$$

Berdasarkan hasil analisis pada tabel 11, uji regresi linear 2 diperoleh bahwa signifikansi anova sebesar 0,330 lebih besar dari $\alpha=0,05$, dengan koefisien yang bernilai positif, maka dengan demikian dapat disimpulkan bahwa $H_{0}$ diterima, yang berarti bahwa terdapat pengaruh positif dan tidak signifikan kecerdasan emosional terhadap prestasi belajar matematika siswa. Selain itu diperoleh koefisien determinasi $\left(\mathrm{R}^{2}\right)$ sebesar 0,010 , yang artinya variabel bebas kecerdasan emosional menjelaskan atau memprediksi variabel terikat prestasi belajar matematika hanya sebesar $1 \%$, sisanya $99 \%$ dijelaskan oleh variabel lain.

Hasil ini sejalan dengan hasil penelitian yang dilakukan oleh Alzak dan Rustam (2015) yang menyatakan bahwa kecerdasan emosional siswa dikatakan berpengaruh tidak signifikan terhadap prestasi belajar matematika siswa. Namun hasil penelitian ini tidak sejalan dengan hasil penelitian yang ditemukan oleh Aswin (2018) yang menyatakan bahwa kecerdasan emosional berpengaruh positif dan signifikan terhadap prestasi belajar siswa.

Adanya perbedaan hasil penelitian tersebut bisa terjadi karena beberapa alasan, diantaranya adalah adanya perbedaan metode dan situasi ketika penelitian dilakukan. Pembelajaran yang diterapkan di sekolah ini hanya berorientasi pada pengetahuan dan pengembangan kecerdasan intelektual, sedangkan untuk pengembangan kecerdasan emosional sendiri belum diperhatikan. Guru masih belum menyadari pentingnya kecerdasan emosional dalam membantu proses belajar siswa. Gusniwati (2015) menjelaskan bahwa siswa yang cerdas secara emosi memiliki kemampuan memotivasi diri dengan baik dan bisa mengendalikan emosinya sehingga mampu memusatkan perhatiannya terhadap pelajaran matematika. Jadi, dengan adanya kecerdasan emosional dalam belajar matematika, siswa akan mampu mengendalikan emosinya dan memotivasi dirinya untuk mencapai prestasi belajar yang lebih baik.

c) Pengujian Hipotesis 3

Terdapat pengaruh positif dan signifikan adversity quotient terhadap prestasi belajar matematika siswa. Dalam hipotesis statistik adalah sebagai berikut:

$$
H_{0}: \beta_{3} \leq 0 \text { lawan } H_{1}: \beta_{3}>0
$$

Berdasarkan hasil analisis pada tabel 11, uji regresi linear 3 diperoleh bahwa signifikansi anova sebesar 0,123 lebih besar dari $\alpha=0,05$, dengan koefisien yang bernilai positif, maka dengan demikian dapat disimpulkan bahwa $H_{0}$ diterima, yang berarti bahwa terdapat pengaruh positif dan tidak signifikan adversity quotient terhadap prestasi belajar matematika siswa. Selain itu diketahui pula bahwa nilai $\mathrm{R}^{2}=0,024$, yang artinya variabel bebas adversity quotient menjelaskan atau memprediksi variabel terikat prestasi belajar matematika hanya sebesar 2,4\%, sisanya $97,6 \%$ dijelaskan oleh variabel lain.

Hasil penelitian ini tidak sejalan dengan hasil penelitian Leonard dan Amanah (2014) yang menyatakan bahwa adversity quotient memberikan pengaruh positif dan signifikan terhadap prestasi belajar matematika siswa. Berbeda dengan penelitian tersebut, ada juga penelitian yang sejalan dengan penelitian ini, yakni penelitian yang dilakukan oleh Hasanah (2010) yang menemukan bahwa tidak ada hubungan yang signifikan antara adversity quotient dengan prestasi belajar siswa.

Hasil analisis penelitian ini menunjukkan bahwa tidak ada pengaruh yang signifikan adversity quotient terhadap prestasi belajar matematika, artinya bahwa tinggi atau rendahnya adversity quotient siswa tidak menjamin tingginya prestasi belajar siswa. Hal ini kemungkinan terjadi karena keterbatasan dan situasi yang berbeda saat dilakukannya penelitian. Keadaan atau situasi pandemi yang mengharuskan siswa belajar dari rumah (secara daring) membuat banyak siswa merasa kewalahan dan stres akibat perubahan kebiasaan belajar. Siswa diharapkan mampu 
memposisikan kesulitan sebagai alat untuk memperbaiki diri, bukan sebagai penghambat besar dalam kehidupan yang menyebabkan prestasi belajarnya turun.

d) Pengujian Hipotesis 4

Terdapat pengaruh signifikan gaya belajar, kecerdasan emosional, dan adversity quotient secara bersama-sama terhadap prestasi belajar matematika siswa. Dalam hipotesis statistik adalah sebagai berikut:

$$
H_{0}: \beta_{123}=0 \text { lawan } H_{1}: \beta_{123} \neq 0
$$

Berdasarkan hasil analisis pada tabel 11, uji regresi linear 4 diperoleh bahwa signifikansi anova sebesar 0,611 lebih besar dari $\alpha=0,05$, sehingga dapat dikatakan bahwa $H_{0}$ diterima, yang artinya variabel gaya belajar, kecerdasan emosional, dan adversity quotient secara bersama-sama memiliki pengaruh yang tidak signifikan terhadap prestasi belajar matematika siswa. Selain itu dapat dilihat bahwa nilai $\mathrm{R}^{2}$ yang diperoleh adalah sebesar 0,065 , yang berarti bahwa variabel gaya belajar, kecerdasan emosional dan adversity quotient secara bersama-sama mampu menjelaskan perubahan yang terjadi pada variabel prestasi belajar matematika hanya sebesar 6,5\%. Sedangkan 93,5\% dijelaskan oleh variabel lain diluar variabel yang diteliti.

Berdasarkan tabel 11 juga dapat diperoleh bentuk persamaan regresi sebagai berikut:

$$
\mathrm{Y}=9.201-0.816 D_{1}-4.315 D_{2}-3.172 D_{3}-0.498 D_{4}-5.207 D_{5}-2.165 D_{6}+0.027 X_{2}+0.086 X_{3}+\varepsilon
$$

Lemahnya peranan ketiga variabel yakni gaya belajar, kecerdasan emosional dan adversity quotient terhadap prestasi belajar matematika siswa juga bisa disebabkan karena beberapa faktor lain yang dapat mempengaruhi prestasi belajar metematika siswa yang mungkin lebih dominan, diantaranya minat siswa, perhatian terhadap materi yang dipelajari, motivasi, faktor keluarga, faktor sekolah, faktor lingkungan dan lain-lain (Slameto, 2015). Hasil tersebut juga bisa diperoleh karena beberapa keterbatasan yang dialami saat penelitian ini dilakukan. Salah satunya karena penelitian ini dilakukan di masa pandemi Covid-19, sehingga pembelajaran dilakukan dirumah secara daring yang membuat siswa maupun guru secara fisik dan mental harus beradaptasi dengan hal tersebut. Selama pembelajaran daring, siswa hanya menggunakan aplikasi Whatsapp. Sedangkan Mahmudin (2021) dalam penelitiannya menunjukkan bahwa penggunaan media WAG (WhatsApp Grup) dalam pembelajaran daring mata pelajaran matematika siswa adalah tidak atau kurang efektif.hal itu bisa disebabkan karena kurangnya interaksi antara siswa dan guru selama pembelajaran berlangsung, dimana interaksi hanya siswa dan guru hanya sebatas pemberian tugas oleh guru.

\section{Conclusion}

Berdasarkan hasil dan pembahasan, diperoleh kesimpulan bahwa:

1) Tidak ada perbedaan tipe gaya belajar dalam mempengaruhi prestasi belajar matematika siswa.

2) Kecerdasan emosional memiliki pengaruh yang positif dan tidak signifikan terhadap prestasi belajar matematika siswa.

3) Adversity quotient memiliki pengaruh yang positif dan tidak signifikan terhadap prestasi belajar matematika siswa.

4) Gaya belajar, kecerdasan emosional, dan adversity quotient secara bersama-sama memiliki pengaruh yang tidak signifikan terhadap prestasi belajar matematika siswa.

5) Siswa memiliki berbagai macam gaya belajar, baik yang cenderung hanya pada satu jenis gaya belajar maupun yang cenderung pada dua atau lebih jenis gaya belajar. Dengan gaya belajar terbanyak yang dimiliki siswa adalah gaya belajar auditorial.

6) Kecerdasan emosional siswa berada pada kategori sedang, Adversity quotient yang dimilliki siswa juga berada pada kategori sedang. Sedangkan untuk prestasi belajar matematika siswa berada pada kategori sangat rendah.

\section{References}

Alzak, A., \& Rustam. (2015). Pengaruh minat dan kecerdasan emosional terhadap prestasi belajar matematika siswa SMP. Jurnal Kajian Pendidikan dan Pengajaran. 1(2). 120-127.

Aswin. (2018). Pengaruh efikasi diri, kecerdasan emosional, dan motivasi belajar terhadap prestasi belajar matematika siswa kelas XI IPA (Skripsi, tidak dipublikasikan). Universitas Negeri Makassar. 
Bire, A. L., Uda G., \& Josua B. (2014). Pengaruh gaya belajar visual, auditorial, dan kinestetik terhadap prestasi belajar siswa. Jurnal Kependidikan. 44(2). 168-174.

Daud, F. (2012). Pengaruh kecerdasan emosional (eq) dan motivasi belajar terhadap hasil belajar biologi siswa sma 3 negeri kota palopo. Jurnal Pendidikan dan Pembelajaran. 19(2). 243-255

DePorter, B. \& Hernacki, M. (2009). Quantum learning : membiasakan belajar nyaman dan menyenangkan. Bandung : Kaifa

Goleman, D. (2002). Kecerdasan emosional. Jakarta : PT Gramedia

Gusniwati, M. (2015). Pengaruh kecerdasan emosional dan minat belajar terhadap penguasaan konsep matematika siswa SMAN di kecamatan kebon jeruk. Jurnal Formatif. 5(1). 26-41.

Hasanah, H. (2010). Hubungan antara adversity quotient dengan prestasi belajar siswa smun 102 Jakarta timur (Skripsi, dipublikasikan) Universitas Islam Negeri Syarif Hidayatullah Jakarta.

Leonard \& Amanah, N. (2014). Pengaruh adversity quotient (aq) dan kemampuan berpikir kritis terhadap prestasi belajar matematika. Perspektif Ilmu Pendidikan. 28 (1). 55-64.

Mahmudin. (2021). Efektifitas penggunaan whatsapp dalam pembelajaran daring mata pelajaran matematika. Seminar Nasional Pendidikan Matematika. 2(1). 263-270

OECD. (2016). Country Note: Indonesia. Program for international student assessment (PISA) Resul from PISA 2015. https://www.oecd.org/pisa/PISA-2015-Indonesia.pdf (diakses pada 25 Januari 2020)

OECD. (2016). Country Note: Indonesia. Program for international student assessment (PISA) Resul from PISA 2018. https://www.oecd.org/pisa/publications/PISA2018_CN_IDN.pdf (diakses pada 25 Januari 2020)

OECD. (2019). PISA 2018 Results : Combined executive summaries volume I, II, \& III. https://www.oecd.org/pisa/Combined_Executive_Summaries_PISA_2018.pdf (diakses pada 25 Januari 2020)

Prihatin, M. S. (2017). Pengaruh fasilitas belajar, gaya belajar dan minat belajar terhadap hasil belajar mata pelajaran ekonomi siswa kelas $x$ iis sma negeri 1 seyegan tahun ajaran 2016/2017 (Skripsi, dipublikasikan). Universitas Negeri Yogyakarta.

Rahman, A. \& Ahmar, A. S. (2017). Relationship between learning style and learning achievements in mathematics based on gender. World Transactions on Engineering And Technology Education. 15 (1). 74-77

Slameto. (2015). Belajar dan faktor-faktor yang mempengaruhi. Jakarta: Rineka Cipta

Stoltz, P. G. (2005). Adversity quotient : mengubah hambatan menjadi peluang. Jakarta : PT Grasindo.

U.S., Supardi. (2013). Pengaruh adversity qoutient terhadap prestasi belajar matematika. Jurnal Formatif. 3(1). 61-71

Uno, H. B. (2006). Orientasi baru dalam psikologi pembelajaran. Jakarta : Bumi Aksara

Wardiana, I. P. A., Wiarta, I. W., \& Zulaikha, S. (2014). Hubungan antara adversity quotient (AQ) dan minat belajar dengan prestasi belajar matematika pada siswa kelas V SD di kelurahan Pedungan. Jurnal mimbar PGSD Universitas Pendidikan Ganesha. 2(1).

Widyawati, S. (2016). Pengaruh gaya belajar terhadap prestasi belajar mahasiswa program studi pendidikan matematika (IAIM NU) Metro. Jurnal Pendidikan Matematika. 7(1). 107-114.

Yanti, A. P. \& Syazali, M. (2016). Analisis proses berpikir siswa dalam memecahkan masalah matematika berdasarkan langkah-langkah bransford dan stein ditinjau dari adversity quotient. Jurnal Pendidikan Matematika. 7(1). 64-74 